\title{
Factors Influencing Students' Decision Making in Selecting University in Bangladesh
}

\author{
Md. Aminul Islam ${ }^{1 *}$, Nehal Hasnain Shoron ${ }^{2}$ \\ ${ }^{1}$ Dept. of Media Studies and Journalism, University of Liberal Arts, Bangladesh \\ ${ }^{2}$ Department of Economics, Pabna University of Science and Technology, Bangladesh \\ * Corresponding author email: aminul.vu@gmail.com
}

Received: 08 May 2019 / Accepted: 25 June 2019 / Published: 18 July 2019

\begin{abstract}
This study investigates the factors that influence students' decisions when choosing a university for higher education in Bangladesh. The study was conducted among students of two private universities in the country. A multi-method approach was adopted in collecting and analyzing data. The responses of the 153 participating students to the questionnaire are primarily described using descriptive statistics, e.g., frequencies, percentages, means, standard deviations, and rankings. Statistical tools like chi-square and ANOVA test are also applied where necessary. Results of the study indicate that the distance of the university from the students' home plays an influential role in university choice process in the country. It is also found that there is a significant association between the level of education at which students first consider studying university and their choice about the university. Several other factors: university's location, cost of tuition, availability of scholarship, students' mother, friend and visits to campus play an influential role in university choice process.
\end{abstract}

Keywords: Decision Making, Choice, Higher Education, Bangladesh University.

\section{Background}

Choice is an inevitable component of human lives. An individual has to make numerous choices throughout life. The decision making is a process of making a choice between options as to a course of action. It can array from fast, intuitive (Hall, 2002; Matzler, Bailom, Mooradian, 2007), or heuristic judgment (Hicks, Kluemper, 2011) through to well-reasoned, analytical and evidence-based. Empirical research on decisionmaking had begun between 1940s and 50s (Patel, Kaufman, and Arocha, 2002; Goldstein, William, Hogarth, 1997). Historically, education has always been a choice. The concept of consumer educational choice (Foskett \& Hemsley-Brown, 2001) got much attention in the debate on higher education in last quarter of the twentieth century. The reality is that students are viewed as educational consumers today.

In the past few decades, Bangladesh has experienced an unprecedented expansion of higher educational institutions, most of which are private. There are 145 universities in the country which is home to about 16 million people. Of the universities, 40 are state run or public, 101 are private and three are international universities (UGC, 2018). Increased demands for skilled workforce fueled by expansion of economy and government's policies have contributed to the rise of the universities. Moreover, a thriving new middleclass population has also created the demand of higher education resulting increasing number of private universities in the country. Private universities are intensely competing to attract new students. They are adopting multiple techniques to attract the students. Several researches (such as Siddiqi, 2016) have tried to understand the phenomenon of the rise of private universities and their role in the country. But the characteristics of decisions made by students to enter the universities are not well understood as students' perspectives of university choice decision have remained unexplored. To fill the gap, the current research tried to understand the students' motivations in making decision to choose a university for higher education in Bangladesh. 
The university choice decision is complex and multi-factorial as Senga Briggs (2006) found that academic reputation, distance from home and location are the most influencing factors for undergraduate students' choice of university in Scotland. Meanwhile, Dao and Thorpe (2015) identified nine key factors that influence student decisions of choosing a university in Vietnam. The factors include facilities and services, price, offline information, opinions, online information, ways of communication, program additions, and advertising. Moreover, residency status, quality and other academic environment characteristics, workrelated concerns, spouse considerations, financial aid, and the campus social environment can play influential role in choosing a university by graduate students (Kallio, 1995). Jsk Ming (2010) investigated the institutional factors that influence students' college choice decision in Malaysia. The researcher found that college's location, diversity of programs, college reputation, educational facilities, cost and availability of financial aid, employment opportunities, advertising, college representatives and campus visit played influential role in this process. While, most of the researches on the topic were conducted among various level of university students, Parivash Jafari and Abdollah Aliesmaili (2013) took a different approach. They investigated the factors influencing university choice among pre-university students in Iran. They identified four sets of factors which played determining role in choosing university. The factors are economic factors, university-related factors, personal factors, and social factors. Roushdy (2012) argued that the factors which influence students' decision in choosing university can be divided into two categories: economic factors and non-economic factors. The economic factors include the cost of university tuition, availability of scholarships and grants, accommodation (room and board). Meanwhile the non-economic factors are university size, and location. Andriani Kusumawati (2013) investigated the factors that influence student choice in the selection of public university Indonesia. The researcher found that cost, reputation, proximity, job prospect and parents are the most influential factors in choosing a university in the country. In general, the findings of the studies can be divided in five categories such as geography, financial, academic excellence and reputation, parents and peers and marketing.

However, the aim of this study is to determine the factors that influence freshmen's decision when choosing university for higher education in Bangladesh. The specific objectives of the study are: To find out the factors that influence students' university selection process and to find out the traditional allegiance to students choosing a particular university.

\section{Methodology}

The study is mainly based on primary data and the results are drawn by the help of descriptive statistics from the collected data. In this descriptive study data were collected from the two private universities in Bangladesh through use of the questionnaire survey method without deliberate manipulation of variables or control over the research settings.

\subsection{Sample Selection and Data Collection}

For conducting present study, the researchers selected the study area with great care so that the estimated results become representative. The sample students are chosen randomly using multistage random sampling method. At first, two divisions are selected randomly which are Dhaka and Rajshahi. Dhaka is the capital city of Bangladesh and Rajshahi, locates about $300 \mathrm{~km}$ north-west of the capital. Then a private university from each of the two areas is selected randomly. Here, University of Liberal Arts Bangladesh (ULAB) is selected from Dhaka and Varendra University (VU) is selected from Rajshahi. Finally, a total of 153 students, who have recently enrolled in different undergraduate level programs, were chosen randomly from the two universities as the target population. In this process, 87 students were chosen from the VU and 66 students were chosen from the ULAB.

To collect the required data, a well-structured questionnaire was constructed, utilizing information derived from the earlier pilot survey. In this process, the questionnaire was validated by two small groups of students from each of the two universities as part of the development process. The critical comments regarding style, format, and appropriateness of questions suggested by those groups were helpful. After these pretests, 
Islam et al., Adv. J Social Sci.; Vol. 6 Issue 1, pp: 17-25, 2020

the questionnaire was designed to collect information about: personal background, parents and family; values and goals of both the student and parents; sources of influence; and factors of significance.

\subsection{Data Analysis}

The responses of the 153 participating students to the questionnaire are primarily described using descriptive statistics, e.g., frequencies, percentages, means, standard deviations, and rankings. The data are presented in tables and graphs. The Statistical Program for the Social Sciences (SPSS) is used to prepare and analyze the data. Where appropriate, statistical tests such as $\chi^{2}$-test and analysis of variance (ANOVA) are used to determine the significance of association and differences between and among groups. Thus, these tests are used to determine which factors are responsible in university choice.

\section{Results}

The analyses procedure of the collected data is presented in this section. The collected data have been edited carefully for correcting any kind of bias and inconsistency so that the error is minimized. The result is summarized in the following sections.

\subsection{Characteristics of Students}

\subsubsection{Gender}

Gender is a very sensitive issue in the country like Bangladesh. From the collected data it is found that males form the majority of participants at each university. It is representative to our higher education system. The percentage distribution illustrated in Figure 1 indicates that $58.6 \%$ from $\mathrm{VU}$ and $66.7 \%$ from ULAB are male students. Albeit, the percentage of female students is less than their male counterparts in both universities, the gap is wider in ULAB. This is because majority of the households don't want to study their female members in a more distant place from the house.

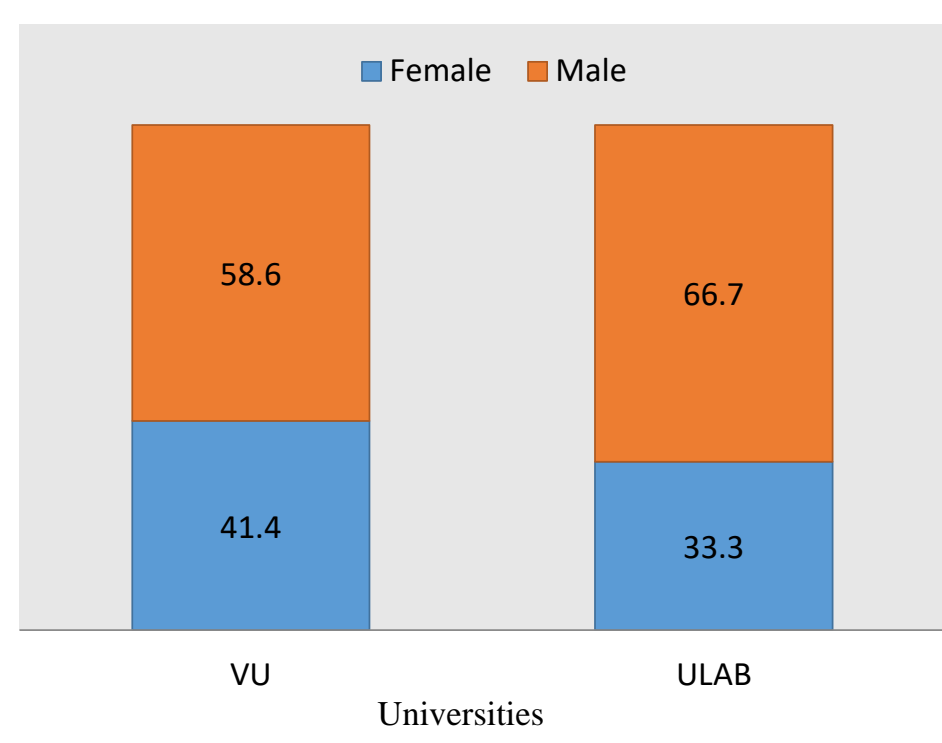

Figure 1: Percentage Distribution of Female and Male Students

\subsubsection{HSC Result}

Each university sets a minimum average entrance requirement in terms of SSC and HSC results. The study gives importance on $\mathrm{HSC}$ result because it is the last stage before attending any university. Table 1 indicates the distribution of HSC result reported for each university.

Table 1: Self-Reported HSC Results of the Respondents

\begin{tabular}{|c|c|c|c|c|}
\hline University & Minimum & Maximum & Mean & Std. Deviation \\
\hline ULAB & 2.00 & 5.00 & 4.02 & 0.64 \\
\hline VU & 2.30 & 5.00 & 4.06 & 0.63 \\
\hline
\end{tabular}

It is seen that ULAB has the broadest range reported with a minimum of Cumulative Grade Point Average (CGPA) 2.00 and a maximum of CGPA 5.00. The average CGPA of the respondents of this university is 4.02. VU also reported similar ranges with CGPA 2.30 to 5.00. The calculated mean result of the respondents of this university is 4.06, a little bit higher than ULAB. According to the result of analysis of variance (ANOVA) the differences among the mean scores are not statistically significant at $p=0.595>$ 
Factors Influencing Students' Decision Making in Selecting University in Bangladesh

0.05. This indicates that the self-reported mean grades of VU and ULAB samples are not significantly different.

\subsubsection{Distance from Home}

Data gathered regarding distance from the students' home to the university are grouped in five categories: 0 - 50 kilometers $(\mathrm{km}) ; 51-100 \mathrm{~km} ; 101-150 \mathrm{~km} ; 151-200 \mathrm{~km}$ and more than $200 \mathrm{~km}$. Fifty km is arbitrarily chosen as the distance which allows students to go home on weekends. Figure 2 states that the highest percentage of the students (89.4\%) at ULAB lives near $50 \mathrm{~km}$ of the institution and an additional $7.5 \%$ live within 51 to $200 \mathrm{~km}$ of the university. Only 3\% students' family lives in distance more than $200 \mathrm{~km}$.

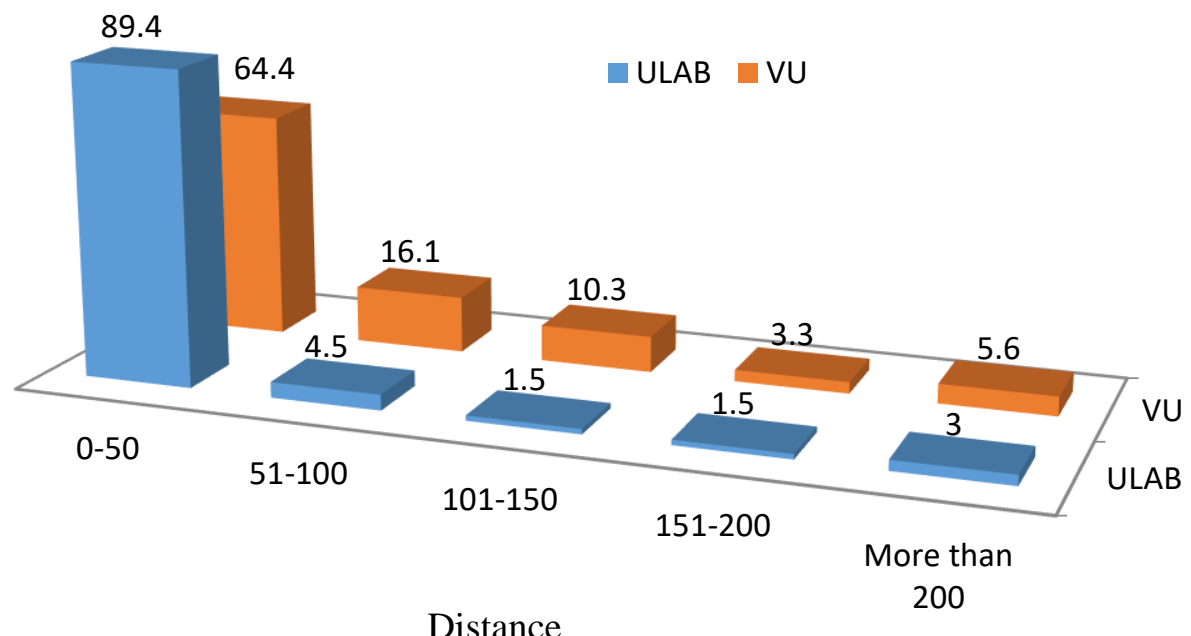

Figure 2: Comparison of Respondents on Distance of Family Home from the Two Institutions

Again, VU samples responded that $64.4 \%$ students' family lives near $50 \mathrm{~km}$ of the university. Moreover, $29.7 \%$ students' traveling distances are greater than $50 \mathrm{~km}$ and less than $200 \mathrm{~km}$. However, $5.6 \%$ students' travel more than $200 \mathrm{~km}$. From the result of ANOVA ( $p=0.026<0.05)$, it is found that the distance of students' home from the university is significantly different. It means the distance of the university from the students' home has the significant effect on university choice.

\subsection{Values and Goals}

\subsubsection{Education Level at which Students First Considered Attending University}

Students do vary at what education level they first considered attending university. From the sample it is observed that all the students at each university considered attending university before completing class XII as shown in Figure 3.

In ULAB, almost half (48.5\%) of the students considered studying university between class XI and XII. Rest of the students $(51.5 \%)$ wanted to study university before class $\mathrm{X}$. In case of VU more than half students $(52.9 \%)$ tended to remember thinking about university admission between classes VI-X.

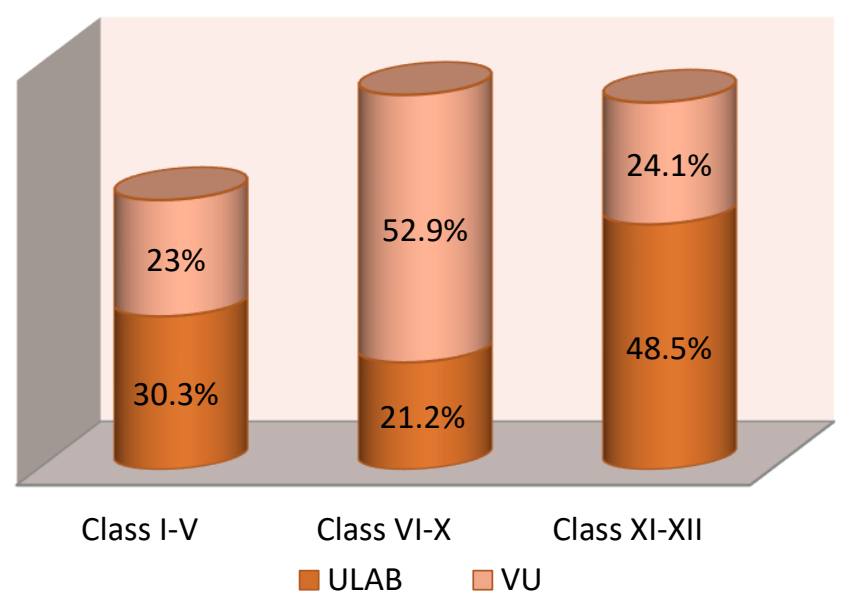

Figure 3: Education Level at which Respondents First Considered Attending University 
Islam et al., Adv. J Social Sci.; Vol. 6 Issue 1, pp: 17-25, 2020

From the chi-square test, it is found that there is a significant association between the level of education at which students first consider studying university and their choice about university $(\chi 2=16.78$, df $=2$, $\mathrm{p}=0.00<0.05)$.

\subsection{Persons, Sources and Factors of Significance}

\subsubsection{Relative Importance on Information of Selected Persons}

This study is designed to determine those factors that students consider influential or significant during the university selection process. In order to rank them and to highlight differences the study uses likert scale. The resulting ratings are presented in Tables 2, 3, and 4. There are almost similar responses from the students of the two universities about the persons of influence and information in choosing a university. The students of both universities ranked the most important persons of information and influence as follows:

i) mother and ii) friends. Collectively mothers are rated the most influential person. This rating perhaps could be attributed to the active role most mothers are believed to play in their children's moral education.

Table 2: Relative Importance on Information of Selected Persons

\begin{tabular}{|c|c|c|c|c|}
\hline \multirow{2}{*}{$\begin{array}{c}\text { Persons of influence } \\
\text { and information }\end{array}$} & High & Low & High & Low \\
\hline High school teacher & 33.4 & 3.0 & 19.5 & 10.3 \\
\hline College teacher & 36.4 & 1.5 & 33.3 & 10.3 \\
\hline Mother* & 65.2 & 4.5 & 68.9 & 6.9 \\
\hline Father & 71.2 & 6.0 & 70.1 & 5.7 \\
\hline Friend* & 54.5 & 15.1 & 47.1 & 12.6 \\
\hline Relative & 35.4 & 21.6 & 43.6 & 10.3 \\
\hline * Chi-square significance at $p<0.05$ & & & \\
** Percents will not add up to 100 because zero and middle category are omitted & & \\
\hline
\end{tabular}

\subsubsection{Relative Importance on Sources of Influence and Information}

Albeit, there is a similarity in responses about the persons of influence and information between the two universities, the characteristics of the students do vary from one university to another in terms of sources of influence and information.

Table 3: Relative Importance on Sources of Influence and Information

\begin{tabular}{|c|c|c|c|c|}
\hline \multirow{2}{*}{$\begin{array}{c}\text { Sources of influence } \\
\text { and information }\end{array}$} & High & Low & High & VU (\%)** \\
\hline Current student & 40.9 & 9.1 & 28.7 & 9.2 \\
\hline Former student* & 45.4 & 13.6 & 17.2 & 10.3 \\
\hline Publication & 31.8 & 10.6 & 21.8 & 16.1 \\
\hline Media* & 28.8 & 9.1 & 13.8 & 11.4 \\
\hline Telephone call* & 24.2 & 12.1 & 9.1 & 16.0 \\
\hline Visit to campus* & 50.8 & 6.2 & 25.2 & 10.3 \\
\hline * Chi-square significance at $p<0.05$ & & & \\
\hline$*$ Percent will not add up to 100 because zero and middle category are omitted & & \\
\hline
\end{tabular}

Students who chose to attend ULAB appear to be influenced by visit to campus, recommendation from former and current students, publications, media and telephone call. Since the highest percentage (50.8\%) of the ULAB students has given importance to the visit to campus, it tends to dominate the decisionmaking process of this institution. However, the students of VU valued recommendation of the current students as the most important sources $(28.7 \%)$, followed by visit to campus $(25.2 \%)$, publication $(21.8 \%)$, recommendations from former students $(17.2 \%)$, media $(13.8 \%)$ and telephone call $(9.1 \%)$. It is also observed from the result that the percentage in every category of sources is higher in ULAB than VU that means the students of ULAB give more emphasis on the above sources in choosing a university than the students of VU. 
Factors Influencing Students' Decision Making in Selecting University in Bangladesh

\subsubsection{Significance of Selected Factors}

The most important factors of significance to the ULAB students are i) availability of scholarship $(63.7 \%)$, ii) university's location (51.5\%), and iii) cost of tuition (50\%). In contrast, VU students highly recommended the factors such as, i) cost of living $(58.6 \%)$, ii) university's location $(55.1 \%)$, and iii) cost of tuition $(54.0 \%)$.

Table 4: Significance of Selected Factors

\begin{tabular}{|l|c|c|c|c|}
\hline \multirow{2}{*}{\multicolumn{1}{|c|}{ Factors of significance }} & \multicolumn{2}{|c|}{ ULAB (\%) ** } & \multicolumn{2}{c|}{ VU (\%) ** } \\
\cline { 2 - 5 } & High & Low & High & Low \\
\hline University's closeness to home & 50.0 & 10.6 & 48.2 & 9.1 \\
University's location & 51.5 & 7.6 & 55.1 & 9.1 \\
availability of housing & 36.7 & 15.2 & 51.7 & 12.6 \\
Cost of living* & 36.3 & 18.2 & 58.6 & 11.5 \\
Cost of tuition & 50.0 & 15.1 & 54.0 & 11.4 \\
availability of scholarship & 63.7 & 9.1 & 42.5 & 13.7 \\
reputation of the institution* & 72.7 & 4.5 & 50.5 & 10.3 \\
Eligibility to apply & 54.5 & 6.0 & 64.3 & 8.0 \\
Variety of courses offered* & 56.1 & 4.5 & 41.3 & 12.6 \\
Family tradition & 35.4 & 10.8 & 39.0 & 9.1 \\
preparation for graduation* & 44 & 4.5 & 62.7 & 10.4 \\
\hline
\end{tabular}

* Chi-square significance at $\mathrm{p}<0.05$

** Percents will not add up to 100 because zero and middle category are omitted

The factors which tend to be significant to students at the ULAB are not the same to students attending VU. VU students rated availability of housing, cost of living and preparation for graduation as important factors in their choice. Conversely, availability of scholarship, reputation of the institution and variety of courses offered were given more importance by the ULAB students. Besides, several factors were given similar importance by the students at both universities such as university's closeness to home, university's location, cost of tuition and eligibility to apply. A chi-square analysis among the influential factors, persons and information indicates that there is a significant relationship between the choice of university and the following factors: mother, friend, former student, media, telephone call, visits to campus, cost of living, reputation of the institution, variety of courses offered and preparation for graduation.

\subsection{Family Tradition}

ULAB students show a tendency to tradition, that is, family members having attended the same institution before. Table 5 illustrates the percentage of father, mother, brother, sister and other relatives who had attended the same university. In almost each case ULAB shows a consistently higher percentage than VU. Chi-square distribution shows that there is a significant relationship between students' choice of university and the probability of studying their father or brother at the same university.

Table 5: Percentage of Respondents' Family Members who Attended Same University

\begin{tabular}{|c|c|c|c|c|}
\hline \multirow{2}{*}{ Family members } & \multicolumn{2}{|c|}{ Yes } & \multicolumn{2}{c|}{ No } \\
\cline { 2 - 5 } & ULAB & VU & ULAB & 100 \\
\hline Father* & 6.1 & 0 & 93.9 & 100 \\
\hline Mother & 3 & 0 & 97 & 100 \\
\hline Brother* & 6.1 & 0 & 100 & 100 \\
\hline Sister & 0 & 0 & 84.5 & 75.9 \\
\hline Other relatives & 15.2 & 24.1 & & \\
\hline
\end{tabular}

* Chi-square significance at $\mathrm{p}<0.05$ 


\section{Discussion}

The following section includes a discussion of the major findings of the study organized according to each research objective. The first objective of the study is to find out the factors that influence students' university selection process. To fulfill the first objective the following areas of examinations are included in this study:

- Characteristics of student, such as; gender, result, distance of the university from family

- Values and goals, such as, education Level at which students first considered attending university

- Persons, sources and factors of significance

\subsection{Characteristics of Students}

The characteristics of the student do vary from one university to another. Gender parity in education system is very essential in Bangladesh. The analysed result indicates that females are lagging behind at each university than their male counterparts. It is representative to our higher education system. The country gained gender equity at primary level, but it is not the case at higher education. Students at both universities appeared most academically able, based on self-reported HSC result as the measure used to assess ability of admission on the institutions. The entrance requirement dictate that no student will be accepted with a CGPA lower than 2.00. Students who chose to attend ULAB and VU had similar CGPA averages (4.02 and 4.06, respectively). The distribution of minimum result indicates CGPA 2.00 for ULAB and 2.30 for VU. Students at the ULAB reported the highest percentage (89.4\%) of students whose family home is in the area between $0-50 \mathrm{~km}$ near the institution. Students attending VU usually live within $0-50 \mathrm{~km}$ of the institution but much lower than ULAB. Most of the students stated that a university with smaller distance is very important. Parents do not agree to admit their children in a university having long distance from family home. However, some students are as likely to come from distances greater than $200 \mathrm{~km}$.

\subsection{Values and Goals}

The decision to attend university does vary from one university to another. A majority of students from the VU indicated that deciding to attend university had occurred as early as high school (class VI-X). On the other hand, almost half of the ULAB students decided to attend university at college level (class XIXII). It appears that VU students have made educational plans and set goals earlier than the ULAB students.

\subsection{Persons, Sources and Factors of Significance}

Students from both institutions rated mothers and friends as clearly the most important persons in a position to influence their decision. Clearly, mothers are influential people in the college or university selection process. Mother affects the process through information dissemination or with her personal involvement. The economic contribution modern mothers are making to the family may have changed the nature of role of mother in the choice process. Friends also play important role in making decision about university admission when they grow up. Most of the times, students are influenced by the decision of their friends. Among various sources of information, students who chose to attend the ULAB appeared to be influenced by visit to campus, recommendation from former and current students, publications, media and telephone call. Since $89.4 \%$ of the ULAB students have family homes between $0-50 \mathrm{~km}$ from the institution, visit to campus tended to dominate the decision-making process. Rating campus visit as a very influential factor in the university selection process is intellectually a more respectable response. However, students of VU valued the recommendations from current students as the most important sources, followed by visit to campus, publication, recommendations from former students, media and telephone call. It is also observed that the percentage in every category of sources of influence and information is higher in ULAB than VU. It means that the students of ULAB give more emphasis on the sources in choosing a university than the students of VU. At the same time, the chi-square test indicates that recommendations from former students, media, telephone call and visit to campus have significant influence on the students of both 
institutions. The factors which tend to be significant to students at the ULAB are not the same to students attending VU. Availability of housing, cost of living and preparation for graduation are rated as influential factors by VU students. The first two features are characteristics of those institutions where students want to attend with low education cost. Availability of housing and cost of living are given importance because housing is available at an affordable cost and living in a smaller city would be less expensive than in the large city. In addition, preparation for admission test is different for different university. As the students admitted themselves in the VU, it may be said that they prepared for the admission of this university. Conversely, ULAB students give more importance on availability of scholarship, reputation of the institution and variety of courses offered. As the university locates at the capital city of Bangladesh and has specialized courses, it has a good reputation to the students. Besides, several factors were given similar importance by the students at both universities such as university's closeness to home, university's location, cost of tuition and eligibility to apply. The rating of tuition costs as an influential factor at ULAB is a puzzle. ULAB levies tuition fees that are clearly higher than VU. A possible explanation for this rating could be that students confused between the tuition costs of all university and the university located at the same city (Dhaka) and did find them to be much lower. In addition, several factors are appeared as significant in decision making for both universities according to the result of chi-square test. Those factors are cost of living, reputation of the institution, variety of courses offered and preparation for graduation.

\subsection{Family Tradition}

The second objective of the study is to find out the traditional allegiance to students choosing a particular university. To know the answer of this objective the study examines about family tradition in attending university. The result indicates that ULAB students follow some family tradition in attending a particular university. Here, fathers and brothers usually lead the tradition. This result may be explained as the VU is a newer institution compared to the ULAB, there would be a less probability that the family members of VU students studied the same university.

\subsection{Policy Implication Suggestion}

The study has a highly practical significance. The results should be of interest to educational institutions particularly private universities in Bangladesh. The results generate some important insight and put significant contribution to existing knowledge body as an understanding of the motivations of students in choosing university will help the institutions make policy, strategy and implement for attracting prospective students. It would also help to improve the qualities and facilities of universities. The improvement of the universities would contribute the national development of the country.

The findings of this study have implications for the participating universities as well. Each institution uses a variety of strategies to provide students with information and to encourage students to apply for admission. Since results of this research indicate that parents, particularly mothers, are clearly the most influential person in the process, it is recommended that universities also advertise to mothers. This may involve articles in publications read by women, specific information made available at community locations, or a direct approach in the literature sent to the student. Students do plan at various grade levels in primary, high school and college levels. Universities generally focus marketing strategies at college students, however, directing appropriate information to students in primary and high school could be another effective approach to influencing student choice.

\section{Conclusion}

Results of the study show that there is a significant relationship between the choice of university and the following factors: university's location, cost of tuition, availability of scholarship, reputation of the institution, variety of courses offered, former student, media presence of university, telephone call from university, students' mother, friend, family tradition, visits to campus and preparation for graduation. The factors which tend to be significant to students at the ULAB are not always the same to students attending 
Islam et al., Adv. J Social Sci.; Vol. 6 Issue 1, pp: 17-25, 2020

VU. VU students rated availability of housing, cost of living and preparation for graduation as important factors in their choice. Conversely, availability of scholarship, reputation of the institution and variety of courses offered were given more importance by the ULAB students. The results indicate that distance of the university from the students' home play an influential role in university choice process in the country. It is also found that there is a significant association between the level of education at which students first consider studying university and their choice about university.

\section{Declaration}

\subsection{Study Limitation}

The main limitation is that the number universities and respondents were kept limited due fund constraints. So, more researches on a broader scale would generate clearer insight in the issue.

\subsection{Competing Interest}

The authors declared that no conflict of interest exist in this work.

\subsection{Informed Consent}

Informed consent was taken from the respondent.

\section{How to Cite this Article:}

Islam, M. A., \& Shoron, N. (2019). Factors Influencing Students' Decision Making in Selecting University in Bangladesh. Advanced Journal of Social Science, 6(1), 17-25. doi: 10.21467/ajss.6.1.17-25

\section{References}

Briggs, S. (2006). An exploratory study of the factors influencing undergraduate student choice: the case of higher education in Scotland. Studies in Higher Education, 31(6), pp.705-722.

Dao, M. and Thorpe, A. (2015). What factors influence Vietnamese students' choice of university? International Journal of Educational Management, 29(5), pp.666-681.

Foskett, N., Hemsley-Brown, J. (2001). Choosing Futures: Young People's Decision-making in Education, Training, and Careers Markets, New York: Routledge

Goldstein, WM, Hogarth, RM, (1997). Judgment and decision making: some historical context. In: Goldstein WM, Hogarth RM, editors. Research on judgment and decision making: currents, connections, and controversies. Cambridge: Cambridge University Press.

Hall, K.H. (2002). Reviewing intuitive decision-making and uncertainty: The implications for medical education, Medical Education, 36 (3): 216-224.

Hicks, E. P., Kluemper, G. T. (2011). Heuristic reasoning and cognitive biases: Are they hindrances to judgments and decision making in orthodontics? American Journal of Orthodontics and Dentofacial Orthopedics, 139 (3): 297-304.

Jafari, P., and Aliesmaili, A. (2013). Factors Influencing the Selection of a University by High School Students. Journal of Basic and Applied Scientific Research, 3 (1): 696-703.

Kallio, R. (1995). Factors influencing the college choice decisions of graduate students. Research in Higher Education, 36(1), pp.109-124.

Kusumawati. A. (2013). A Qualitative Study of the Factors Influencing Student Choice:The Case of Public University in Indonesia. Journal of Basic and Applied Scientific Research, 3 (1): 314-327.

Matzler, K., Bailom, F., Mooradian, T. A. (2007). Intuitive decision making, MIT Sloan Management Review, 49 (1): 150-157.

Patel, V. L. K., David R, and Arocha, J. F. (2002). Emerging paradigms of cognition in medical decision-making, Journal of Biomedical Informatics, 35 (1): 52-75

Roushdy, A.S. (2012). Factors Influence Student's Choice of Universities in Egypt, Journal of American Academy of Business Cambridge, 18: 327-334.

Siddiqi, Hafiz G. A. (2016). Private Universities in Bangladesh: The Dynamics of Higher Education, Dhaka: Academic Press and Publishers Library.

Sarkar, S. H., Rana, S., Zitu, R. A. (2013). Challenges of Quality Higher Education in Bangladesh: A Study on Public Universities, Journal of Education and Practice, 4 (8): 151-160

University Grants Commission (UGC), (2018). List of Universities. Available at: http://www.ugc.gov.bd accessed on June 24, 2018.

Publish your research article in AIJR journals-

$\checkmark$ Online Submission and Tracking

$\checkmark$ Peer-Reviewed

$\checkmark$ Rapid decision

$\checkmark \quad$ Immediate Publication after acceptance

$\checkmark \quad$ Articles freely available online

$\checkmark$ Retain full copyright of your article.

Submit your article at journals.aijr.in
Publish your books with AIJR publisher-

$\checkmark$ Publish with ISBN and DOI.

$\checkmark$ Publish Thesis/Dissertation as Monograph.

$\checkmark$ Publish Book Monograph.

$\checkmark$ Publish Edited Volume/ Book.

$\checkmark$ Publish Conference Proceedings

$\checkmark$ Retain full copyright of your books.

Submit your manuscript at books. aijr.org 